\title{
Basel IV capital requirements and the performance of commercial banks in Africa
}

\author{
Damilola Oyetade $^{1} \cdot$ Adefemi A. Obalade $^{1} \cdot$ Paul-Francois Muzindutsi ${ }^{1}$ (i)
}

Accepted: 17 October 2021 / Published online: 30 October 2021

(c) The Author(s), under exclusive licence to Springer Nature Limited 2021

\begin{abstract}
Capital adequacy is considered an essential determinant banks' performance. Banks in Africa have revenue growth opportunities, but fragility and vulnerability to bank failures arising from capital inadequacy and non-performing loans affect their performances. The Basel Committee aims to introduce higher capital requirements is to strengthen the resilience of the banking system; however, the implementation of higher Basel capital requirements may affect the performance of banks. This study examines the potential impact of Basel IV capital requirements (CAR) on the performance of commercial banks from selected African countries. To achieve the set objective, the study simulated Basel IV CAR to create sample representative bank balance sheets using historical data from 2000 to 2018 because Basel IV CAR has not commenced. The study developed a sample-representative of Basel IV CAR and employed static and dynamic panel regression analyses as the estimation techniques. The results suggest that Basel IV CAR portends short-term negative impacts on bank performance while the long-term impact on bank performance is favorable.
\end{abstract}

Keywords Basel capital requirements $\cdot$ Performance $\cdot$ Banks $\cdot$ Africa

JEL Classification G21 · G28 · G17

\section{Introduction}

The performance of banks is a crucial element to the survival of banks. At the same time, capital regulations are important factors that could be beneficial or detrimental to banks' performance [1]. Due to the nature of banks' business, banks are exposed to many potential risks of operational losses; deposits withdrawal without notice, the state of the economy like recession, COVID-19 pandemic global crises and other factors that create uncertainty in borrowers' loan repayments $[2,3]$. These risks affect the performance, banks' survival, and the banking sector's stability; and their negative effects can spill over to the economy [4]. To manage these effects, regulatory authorities play an important role in establishing adequate regulations that include capital requirements (hereafter CAR) to address the banks' risks [5].

Paul-Francois Muzindutsi

MuzindutsiP@ukzn.ac.za

1 School of Accounting, Economics and Finance, University of KwaZulu-Natal, University Road Westville, Bag X 5400, Durban 4000, South Africa
Nevertheless, the regulatory authorities' decisions to stabilise of the banking sector [6], which includes higher CAR, affect the performance of banks [7].

Banks in Africa generate high income, but capital inadequacies, high levels of non-performing loans, poor asset quality, operational inefficiencies, and macroeconomic factors erode the earnings of these banks that could otherwise be averted by implementing higher Basel levels [8, 9]. Empirical studies identify that banks in Africa are adequately capitalized above the minimum Basel CAR of 8 percent. The average bank capital ratio in Africa is 12 percent $[10,11]$. This could suggest that African banks do not need to comply with Basel III or even Basel IV like banks in the developed countries that fell into a financial crisis with low capital levels. The challenge of the African banks' average capital ratios are; first, the quality and the composition of the high capital ratio declared.

Secondly, some of the banks may not apply the Basel requirements, such as calculating the risk-weighted assets in arriving at their reported capital ratio. As a result, many African banks have capital buffers either above their risk exposures or below their risk exposures. Hence, the growth 
of banks in Africa does not match up with banks from other developing economies except South Africa that has fully embraced Basel II and Basel III CAR. This is among the reasons why this study examines the potential impact of Basel IV CAR on the performance of banks in Africa for policy purpose. The BCBS introduced Basel III in the post-financial crisis to increase the quantity and quality of capital from 8 percent in Basel II to 10.5 percent in Basel III $[12,13]$. The aim was to assist banks to have adequate capital to cover for losses. Furthermore, the Basel IV accord was introduced in 2016 to standardize the calculation of the risk-weighted asset, a denominator of Basel III capital ratio, to avoid different models used by banks. Basel IV accord also provides more transparency in bank disclosures of regulatory capital and comparable capital ratios among banks [14, 15].

The key contributions of this study are twofold. Firstly, it compliments extant literature $[16,17]$ that have examined the potential impact of Basel III before its implementation using sample representative banks drawn from historical data of banks in their respective samples. Following the approach of these studies, the current study provides a forward-looking analysis of the effects of new Basel IV regulations. Since the Basel IV CAR requires tangible common equity, different risk weightings in the calculation of RWA, and standardization of RWA, this study deviates from differs from the existing studies by focusing on the possible impact of Basel IV CAR on the performance of commercial banks in Africa. By doing so, this study also departs from [18] who examined the impact of Basel IV CAR on securitization and performance of securitizing banks in South Africa. Lastly, the current study is also motivated by African banks' lack of inclusion in the global banking system and its fragility despite opportunities for revenue growth in traditional banking as identified by [9] as well as the need to know the possible benefits and cost of adopting new Basel CAR from African perspective.

\section{Theoretical literature on Basel IV CAR and bank performance}

The fundamentals and the composition of Basel capital ratios target the capital structure of any bank. The two competing theories pertinent to this study are the static trade-off theory and the M \& M irrelevance theory. The static trade-off theory states that "optimal capital structure is reached when the tax advantage to borrowing is balanced at the margin by the costs of bankruptcy" [19], suggesting that firms will prefer to hold more debt than equity because of the tax benefit of debt. This principle may conflict with Basel III and IV CAR which requires banks to use equity capital to achieve higher CAR. This has been confirmed by [20,21] found that banks have cost constraints when complying with Basel III
CAR. Based on the static trade-off theory, it is expected that compliance with Basel IV CAR has a negative impact on the performance of banks in Africa. Contrarily to the rade-off theory, Modigliani \& Miller theory suggests that change in the mix of capital does not affect the firm's value [22, 23]. Therefore, suggesting that compliance with Basel framework to increase in regulatory capital for banks will not affect the performance of the banks. However, because equity is expensive (due to no tax-deductible advantage) and scarce [24, 25], it is expected that compliance with Basel IV CAR has a negative impact on the performance of banks in Africa.

\section{Empirical literature on Basel CAR and bank performance}

Very few studies $[1,26,27]$ have been carried out to provide empirical evidence on the impact of Basel III CAR on the performance of banks. Studies from developed countries that examine the impact of Basel III CAR on the performance of banks have produced mixed findings. Le et al. [27] employ OLS to examine Basel III's impact on the profitability of banks by comparing Australia and British banks. They find that compliance with Basel III CAR improved the operating earnings of the banks but fail to boost bank profits and efficiency. Furthermore, [26] find that return on equity increased with higher capital for European banks under Basel III using fixed and random effects for the period between 2013 and 2015. Other bodies of empirical literature found an insignificant impact of Basel III CAR on the performance of banks in the developed countries. Bandt et al. [1] found that Basel III CAR has an insignificant effect on the performance of banks in France. They found that voluntary capital had a positive impact on performance; however, for regulatory capital, there has been a beneficial effect of higher Basel CAR for undercapitalized banks but was offset by the negative impact on other banks. Thus, the average effect is insignificant [1].

Conversely, a handful of other studies [28-30] found a negative relationship between higher CAR and bank performance. Findings of many bank regulation studies from the developed countries suggest that higher CAR exert a negative impact on the performance of banks, thus leading to a conclusion that higher CAR jeopardize the performance of banks [27, 28]. Banks in the developed countries may have falling earnings, which reduces the returns on equity when a higher CAR is adopted; however, these banks strive for improving their performance through cost efficiency [27, 31].

There is ample evidence from emerging countries that higher CAR impact positively on the performance of banks $[32,33]$. Thus, banks in the emerging economies enjoy high earnings and asset growth when they comply with higher CAR and this affect bank performance positively 
[31]. Nevertheless, other studies show that higher CAR has a negative impact on the performance of banks in emerging countries [34, 35]. There are few studies from emerging economies, such as [16] for Indian banks and [36] for banks in Brazil that examine Basel III CAR's impact on performance before it was implementated in their economy. The relationship between capital and bank performance continues to be a fundamental point of discussion in the literature, and findings on the introduction of tighter regulations are often inconclusive. There are few empirical evidence from African countries, for instance, [37] for banks in Mali; [38] in Egypt; and [39] for commercial banks in Nigeria. These studies report that higher capital has a positive impact on bank performance. Nkopane [8] examined the determinants of profitability for commercial banks in Sub-Sahara Africa for the period 1996 and 2006. Using fixed and random effect models, the study found that capital adequacy positively impacts bank performance. The policy implication was that bank regulators and policymakers should pay attention to bank-specific and macro-economic factors that influence the bank's profitability.

Contrariwise, there are studies $[11,40,41]$ which show that higher CAR negatively impacts on bank performance from African countries. Other studies such as [42] found no relationship between Basel CAR and the performance of banks in Middle-East and North African countries. Some African countries choose not to adopt changes in Basel levels as they are considered stringent and non-compliance to the structure of their local banking system [43, 44]. However, [45] establish that permissive and self-regulation is insufficient for stable financial systems. This study fills a gap in the literature by providing evidence of the possible impact of Basel IV CAR on the performance of banks in selected African countries with bank-level data. It should be noted that, econometric estimates are subjected to high uncertainty, when evaulting an uneimpled policy. This study is not an exception as it is based on calibrations employed by similar studies to examine the potential impact of Basel IV on the performance of banks in Africa.

\section{Methodology for Basel IV CAR and bank performance}

This study used panel data sourced from multiple online databases. Bank performance and financial data were obtained from Bloomberg database as the main database, and additional financial information was sourced from S\&P Capital IQ database. The macroeconomic data were collected from Reserve banks of selected African countries, World Bank, and Infront database. The total population from Bloomberg and S \& P capital IQ database consists of
Table 1 Panel data of banks from selected African countries. Source: Authors' compilation (2020)

\begin{tabular}{ll}
\hline Country & No of banks \\
\hline Botswana & 3 \\
Egypt & 6 \\
Ghana & 2 \\
Kenya & 7 \\
Mauritius & 1 \\
Morocco & 1 \\
Namibia & 1 \\
Nigeria & 9 \\
South Africa & 6 \\
Swaziland & 1 \\
Tanzania & 2 \\
Uganda & 1 \\
Zimbabwe & 1 \\
Total & 41 \\
\hline
\end{tabular}

137 commercial banks that are listed on stock exchanges in Africa.

The study employed two criteria to select the sample size. First, the study included all commercial banks from each African country with consistent and reliable data for the entire sample period, 2000-2018. The sample period is considered based on the introduction of Basel II in 2004 as this allows the study to draw a conclusion on the impact of Basel IV as if they had been adopted in the period considered vis-à-vis existing Basel regulations. Second, each sampled bank must have complied with Basel II or Basel III capital requirements. The final sample was constituted by an unbalanced panel of 41 banks (from 13 African countries) that have adopted Basel II or III, as shown in Table 1 below:

\section{Sampled bank and simulated capital ratio}

In line with prior studies such as [17] for Luxembourg banks and [16] for Indian banks, this study simulated Basel IV capital ratio according to the Basel IV accord requirements. The study uses aggregated financial data of selected African banks to create sample representative of banks as if these banks had implemented the Basel IV CAR since the year 2000. The Basel IV simulated data was then analyzed and compared to actual data using the regression analysis of choice to examine the possible impact on performance under certain assumptions while holding other conditions constant. The creation of sample representative banks to examine the potential impact of a new regulation is a common and well-accepted practice in the literature $[16,17,46]$. For a more robust comparison, the study 
Table 2 Definition of model variables for Basel IV CAR and performance. Source: Authors' compilation (2020)

\begin{tabular}{lllll}
\hline Variable & Definition & Formula & Expected sign & Source \\
\hline$\pi$ & ROE & Profits before tax/Average shareholders & Dependent variable & [26] \\
Lev & Non-risk leverage $\geq 4$ percent & Tier1 Capital/average-total assets & Negative & [47] \\
Cap & Basel IV capital ratios & Tangible common equity/RWA & Negative & [14] \\
Size & Bankspe & Quintiles of total asset & Positive & Negative \\
Loandp & Bankspe & Loan/Deposit & Negative & [48] \\
Nplta & Bankspe & Nonperforming asset/total loan & Negative & [49] \\
Reporate, Inflat & macroec & Reporate & Positive & [50] \\
Gdpgrowth & macroec & Inflation & Positive & [51] \\
\hline
\end{tabular}

also examines the impact of changes from Basel II to III, on the performance of African commercial banks.

\section{Estimated model for Basel IV CAR and bank performance}

Following [17], this study makes assumptions ${ }^{1}$ to simulate the banks' balance sheets, as explained in the previous section. Based on the simulated data, the study formulates the following model to achieve its objective:

$\pi_{i t}=f\left(\right.$ Cap $_{i t}$, Lev $_{i t}$, Bankspec $_{i t}$, Macroeco $\left._{t}\right)$

where $\pi$, Cap, Lev, Bankspe and macroec are profitability, Basel capital, leverage, bank-specific, and macroeconomic variables, respectively. A detailed explanation of these variables is found in Table 2.

A static model for Basel IV CAR and banks' performance derived from Eq. 1, is as follows: the more efficient estimator among PMG, MG, and DFE [54]. The P-ARDL (p, q, q, ----, q) model is:

$$
\begin{aligned}
\pi_{i t} & =\alpha_{i}+\sum_{j=1}^{p} \lambda_{i j} \pi_{i, t-j} \\
& +\sum_{j=0}^{q} \delta_{1, i j} \text { Cap }_{i, t-j}+\sum_{j=0}^{q} \delta_{2, i j} \text { macroec }_{i, t-j}+\epsilon_{i t}
\end{aligned}
$$

Reparameterization of Eq. (3):

$$
\begin{aligned}
\Delta \pi_{i t}= & \alpha_{i}+\phi_{i} \pi_{i, t-1}+\beta_{1 i}^{\prime} \text { Cap }_{i t-1}+\beta_{2 i}^{\prime} \text { macroec }_{i t-1} \\
& +\sum_{j=1}^{p-1} \lambda_{i j}^{*} \Delta \pi_{i, t-j}+\sum_{j=0}^{q-1} \delta_{i, i j}^{*^{\prime}} \Delta \text { macroec }_{i, t-j}+\sum_{j=0}^{q-1} \delta_{2, i j}^{*^{\prime}} \Delta \text { Cap }_{i, t-j}+\epsilon_{i t}
\end{aligned}
$$

where i represent a specific banks $1 \ldots \mathrm{N}$, $\mathrm{t}$ represents time period 2000, 2001, 2002, ..2018, and $\pi_{i t}$ is the ROE profitability of bank $\mathrm{i}$ at time t. $\phi_{i} \pi_{i, t-1}$ is a lagged dependent variable. Cap $_{i t}$ represents Basel IV variables. macroec $_{i t}$ represents macroeconomic variables (e.g. GDP growth, inflation and

$\pi_{i t}=\beta_{1}+\beta_{2}$ Lev $_{i t}+\beta_{3}$ Cap $_{i t}+\beta_{4}$ Bankspe $_{i t}+\varphi^{\prime}$ macroec $_{t}+\theta^{\prime}$ Year $_{i}+\epsilon_{i t}$

where $i$ represent specific banks $(1 \ldots \mathrm{N})$, t represents time period $(1 \ldots \mathrm{N})$, and $\pi_{i t}$ is the profitability of bank $i$ at time $t$ proxied by ROE, ROA, NIM variables. Considering that static panel estimations, such as fixed and random effects estimations, usually cannot distinguish between short-run and long-run impacts [52], Eq. 3 was developed in line with [53] and [52] to capture the short and long-run impacts of Basel CAR on the performance of banks in Africa using Panel Autoregressive Distributed Lag (P-ARDL) model. Under the P-ARDL model, Eq. 3 was estimated using the pooled mean group (PMG), mean group (MG), and dynamic fixed effects (DFE). The Hausman test was used to determine

\footnotetext{
${ }^{1}$ Assumptions made in the calculation of RWA: Bank assets used in the calculation of RWA are assumed to be AAA. Commercial loans are assumed to be investment grade.
}

interest rate) that explains the effect economic changes on bank performance.

In Eqs. 2 to 4, the coefficient of lagged profits and other explanatory variables $-\beta, \delta, \eta, \theta, \rho, \varphi$ are coefficients in the model. $\alpha_{i}$ and $\gamma_{t}$ controls for unobserved heterogeneity and time-specific effects that influence the dependent variable. $\varepsilon_{i t}$ is the error term for bank $\mathrm{i}$ in year t. Year $_{i}$ - control for year effects by introducing year dummies. Unit root test is necessary to check that none of the variables of P-ARDL models is I2. Unit root results are presented in Table 4. 
Table 3 Summary statistics of key variables. Source: Authors' calculation based on data from Bloomberg database (2020)

\begin{tabular}{lrllrrrrl}
\hline Stats & \multicolumn{1}{l}{ Mean } & N & Min & \multicolumn{1}{l}{ Max } & \multicolumn{1}{c}{ Range } & \multicolumn{1}{c}{ sd } & Variance & Skewness \\
\hline ROE & 20.163 & 883 & -173.5 & 92.900 & 266.400 & 18.382 & 337.881 & -3.461 \\
ROA & 2.688 & 883 & -8.992 & 41.002 & 49.994 & 3.323 & 11.041 & 6.947 \\
NIM & 28.696 & 761 & -42.964 & 92.306 & 135.271 & 14.575 & 212.441 & -0.347 \\
BII_capratio & 16.570 & 551 & 4.000 & 46.000 & 42.000 & 6.389 & 40.821 & 1.274 \\
BIII_capratio & 19.074 & 570 & 2.901 & 73.807 & 70.906 & 8.150 & 66.415 & 1.696 \\
BIV_capratio & 20.832 & 702 & 0.720 & 301.789 & 301.069 & 23.345 & 544.981 & 8.266 \\
Lev & 11.382 & 626 & -22.981 & 94.125 & 117.106 & 9.795 & 95.941 & 4.866 \\
Loan_deposit & 86.966 & 795 & 0.160 & 574.305 & 574.146 & 47.092 & 2217.63 & 3.030 \\
Nplta & 3.994 & 700 & 0.029 & 63.398 & 63.368 & 6.146 & 37.770 & 5.088 \\
Gdpgrowth & 4.810 & 883 & -7.652 & 19.675 & 27.328 & 2.832 & 8.023 & 0.290 \\
Reporate & 5.798 & 793 & -16.307 & 22.686 & 38.993 & 5.827 & 33.956 & 0.110 \\
Inflation & 9.442 & 852 & -2.410 & 32.905 & 35.315 & 5.389 & 29.042 & 1.238 \\
\hline
\end{tabular}

Table 4 Panel unit root test. Source: Authors' calculation based on data from Bloomberg database (2020)

\begin{tabular}{llll}
\hline Variables & ADF & PPT & Stationary \\
\hline ROE & 0.0000 & 0.0000 & $\mathrm{I}(0)$ \\
BIIcap & 0.0000 & 0.0000 & $\mathrm{I}(0)$ \\
BIIIcap & 0.0000 & 0.0000 & $\mathrm{I}(0)$ \\
BIVcap & 0.0000 & 0.0000 & $\mathrm{I}(0)$ \\
Gdpgrowth & 0.0000 & 0.0000 & $\mathrm{I}(0)$ \\
\hline
\end{tabular}

\section{Results and discussion}

Table 3 presents the summary statistics of the key variables; the dependent variables (ROE, ROA, and NIM), and the independent variables, namely Basel capital ratios, bankspecific ratios, and macroeconomic variables. Table 3 shows some interesting features of Basel capital ratios. The simulated Basel IV capital ratio (BIV_capratio), Basel II, III capital ratio (BII_capratio and BIII_capratio) presents a high average mean above the minimum Basel CAR. This could be due to some of the banks having much equity capital that is not utilized to generate more profits due to increasing bank loans, and fear of losses. However, the standard deviation of the BII_capratio and BIII_capratio in Table 3 is low, suggesting that many of the banks have difficulty achieving the minimum CAR. Also, the African banks not utilizing their equity explains why the average return on assets (ROA) is low at 2.68 percent. Some banks may have high non-performing loans ranging to 63.4 percent of total bank assets. This may pose a liquidity threat to banks struggling to survive and lead to erosion of capital due to the high incidence of failing loans.

The loan deposit ratio (loan_deposit) shows that, on average, banks in Africa have a high loan to deposit ratio at 87 percent. Some African banks issue loans five times above their own deposits, with the highest range of the ratio at 574.305. Such banks put themselves under liquidity problems and can face the risk of bankruptcy. Capitec bank South Africa has a high loan_deposit ratio at 574.305. It is also the bank having a high Basel IV capital ratio of 301.7 percent. If Basel III or IV CAR had been implemented in the year these events happened (between 2002 and 2004), the nonrisk weighted leverage ratio would have acted as a backstopper for such banks to either reduce lending or increase their capital level to 301 percent to issue more loans five times above their total deposits. The variables presented in Table 3 are logged for subsequent data analysis to eliminate outliers as shown by the spread between min and max values in Table 3. Also, after logging the dependent and independent variables in the study, the three dependent variables became left-skewed.

\section{Panel unit roots test}

The Augmented Dicker Fuller (ADF) and Phillips-Perron (PPT) unit root test for P-ARDL models are given in Table 4. All the variables are stationary at level using ADF unit root test. The ADF and PPT panel unit root test results for ROE, BIIcap BIIIcap BIVcap and Gdpgrowth show that at level, the $p$ value is significant at 5 percent. Therefore, the study rejects the $H_{0}$ and accept $H_{1}$. The result shows that the variables are stationary at level, so there is no need for further differencing.

\section{Static analysis of Basel IV CAR and bank performance}

Equations 2 was estimated using random effects (RE), and fixed effects (FE) models. The Hausman test rejects fixed effects and confirmed random effects as the efficient 
Table 5 Random effect results for Basel CAR and performance of banks in Africa. Source: Authors' calculation based on data from Bloomberg database (2020)

\begin{tabular}{|c|c|c|c|}
\hline Basel levels & Basel II & Basel III & Basel IV \\
\hline & ROE & ROE & ROE \\
\hline \multirow[t]{2}{*}{ BIIcap } & $0.025 * *$ & & \\
\hline & $(0.011)$ & & \\
\hline \multirow[t]{2}{*}{ BIIIcap } & & 0.066 & \\
\hline & & $(0.057)$ & \\
\hline \multirow[t]{2}{*}{ BIVcap } & & & $0.093^{*}$ \\
\hline & & & $(0.05)$ \\
\hline \multirow[t]{2}{*}{ _Isize_2 } & $0.046 * * *$ & 0.067 & 0.077 \\
\hline & $(0.011)$ & $(0.063)$ & $(0.062)$ \\
\hline \multirow[t]{2}{*}{ _Isize_3 } & $0.045^{* * *}$ & 0.018 & 0.026 \\
\hline & $(0.012)$ & $(0.064)$ & $(0.063)$ \\
\hline \multirow[t]{2}{*}{ _Isize_4 } & 0.021 & 0.023 & 0.027 \\
\hline & (0.013) & $(0.068)$ & $(0.067)$ \\
\hline \multirow[t]{2}{*}{ _Isize_5 } & 0.008 & 0.07 & 0.085 \\
\hline & $(0.015)$ & $(0.082)$ & $(0.081)$ \\
\hline \multirow[t]{2}{*}{ Leverage } & $-0.024 * * *$ & $0.105^{* *}$ & $0.078^{*}$ \\
\hline & $(0.008)$ & $(0.046)$ & $(0.046)$ \\
\hline \multirow[t]{2}{*}{ Loandp } & 0.006 & 0.000 & 0.042 \\
\hline & (0.009) & $(0.052)$ & (0.059) \\
\hline \multirow[t]{2}{*}{ Gdpgrowth } & 0.001 & 0.013 & 0.009 \\
\hline & $(0.005)$ & $(0.029)$ & $(0.029)$ \\
\hline \multirow[t]{2}{*}{ Reporate } & $0.007 * *$ & 0.002 & -0.001 \\
\hline & $(0.003)$ & $(0.02)$ & $(0.02)$ \\
\hline \multirow[t]{2}{*}{ Nplta } & $-0.018 * * *$ & $-0.080 * * *$ & $-0.079 * * *$ \\
\hline & $(0.003)$ & $(0.018)$ & $(0.018)$ \\
\hline \multirow[t]{2}{*}{ Inflat } & $0.027 * * *$ & 0.004 & 0.007 \\
\hline & $(0.006)$ & $(0.04)$ & $(0.039)$ \\
\hline \multirow[t]{2}{*}{ _cons } & $5.359 * * *$ & $4.984 * * *$ & $4.912 * * *$ \\
\hline & $(0.051)$ & $(0.335)$ & $(0.33)$ \\
\hline $\mathrm{N}$ & 383 & 403 & 404 \\
\hline
\end{tabular}

Standard errors are in parentheses $* p<0.1$, ** $p<0.05$, *** $p<0.001$

estimator for Basel III and IV but confirmed fixed effects as the efficient estimator for Basel II. Tables 5 and 6 present the results for random effects. Table 6 presents robust checks using ROA and NIM. The three models in Tables $5 \& 6$ represent each Basel level capital ratio (Basel II, Basel III, and Basel IV capital ratios).

The results for higher Basel CAR on performance using ROE, ROA, and NIM are similar. In this context, BIIcap, BIIIcap, and BIV cap have a positive coefficient on the performance of commercial banks for selected African countries. However, the degree of significant impact differs with the different performance measures used in the analysis. The different degree of impact is consistent with literature that the impact of CAR on bank performance depends on the measure of profitability employed in the study $[55,56]$. The estimation results for ROA and NIM indicate that the coefficient of CAR (BIIcap, BIIIcap, and BIVcap) has a positive and significant impact bank performance. Under ROA model, the significant positive effect CAR on ROA in BII, BIII, and BIV suggests that higher Basel CAR increases banks' efficiency to utilize capital to generate higher returns on assets appropriately. Also, the positive effect on NIM for BIIcap and BIIIcap suggests that higher CAR increased bank lending activities, which increased the banks' interest income. BIVcap has a positive impact on NIM at 10 percent, which means that change from Basel III to Basel IV would result in less interest income for the banks. Of the three performance ratios, higher Basel CAR has a persistent impact on ROA. Nevertheless, ROA and NIM were used as robustness checks by substituting ROE for ROA and NIM in Table 6; therefore, ROE's results are discussed for this study.

The results for higher Basel CAR on performance using ROE, ROA, and NIM are similar. In this context, BIIcap, BIIIcap, and BIV cap have a positive coefficient on the performance of commercial banks for selected African countries. However, the degree of significant impact differs with the different performance measures used in the analysis. The different degree of impact is consistent with literature that the impact of CAR on bank performance depends on the measure of profitability employed in the study $[55,56]$. The estimation results for ROA and NIM indicate that the coefficient of CAR (BIIcap, BIIIcap, and BIVcap) has a positive and significant impact bank performance. Under ROA model, the significant positive effect CAR on ROA in BII, BIII, and BIV suggests that higher Basel CAR increases banks' efficiency to utilize capital to generate higher returns on assets appropriately. Also, the positive effect on NIM for BIIcap and BIIIcap suggests that higher CAR increased bank lending activities, which increased the banks' interest income. BIVcap has a positive impact on NIM at 10 percent, which means that change from Basel III to Basel IV would result in less interest income for the banks. Of the three performance ratios, higher Basel CAR has a persistent impact on ROA. Nevertheless, ROA and NIM were used as robustness checks by substituting ROE for ROA and NIM in Table 6; therefore, ROE's results are discussed for this study.

The results in Table 5 indicate that the coefficients of BIIcap and BIVcap have a positive and significant impact on return on equity. The positive coefficient of 0.025 and 0.093 means that holding other variables constant, a unit increase in BIIcap and BIVcap would lead to about 2.5 percent and 10 percent increase in return on equity. There is no evidence of BIIIcap influencing return on equity as the relationship is statistically insignificant. Basel III CAR is a prerequisite for Basel IV CAR. As such, the significant results under Basel IV model suggest that the banks have adapted to the strict regulations imposed by Basel III CAR, thus enhancing banks' ability to adjust to the implementation of Basel IV 
Table 6 Random effect results for ROA and NIM. Source:

Authors' calculation based on data from Bloomberg database(2020)

\begin{tabular}{|c|c|c|c|c|c|c|}
\hline Basel levels & Basel II & Basel III & Basel IV & Basel II & Basel III & Basel IV \\
\hline & ROA & ROA & ROA & NIM & NIM & NIM \\
\hline \multirow[t]{2}{*}{ BIIcap } & $0.139 * * *$ & & & $0.789 * * *$ & & \\
\hline & $(0.034)$ & & & $(0.126)$ & & \\
\hline \multirow[t]{2}{*}{ BIIIcap } & & $0.082 * *$ & & & $0.412 * * *$ & \\
\hline & & $(0.034)$ & & & (0.104) & \\
\hline \multirow[t]{2}{*}{ BIVcap } & & & $0.109 * * *$ & & & $0.171^{*}$ \\
\hline & & & $(0.029)$ & & & $(0.097)$ \\
\hline \multirow[t]{2}{*}{ _Isize_2 } & 0.011 & 0.008 & 0.021 & $0.249 * *$ & $0.260 * *$ & $0.257 * *$ \\
\hline & $(0.032)$ & $(0.037)$ & $(0.037)$ & $(0.112)$ & $(0.11)$ & $(0.113)$ \\
\hline \multirow[t]{2}{*}{ _Isize_3 } & 0.004 & -0.023 & -0.01 & $0.292 * *$ & $0.294 * * *$ & $0.288 * *$ \\
\hline & $(0.034)$ & $(0.038)$ & $(0.037)$ & $(0.117)$ & $(0.11)$ & $(0.112)$ \\
\hline \multirow[t]{2}{*}{ _Isize_4 } & $-0.062 *$ & -0.067 & -0.059 & 0.198 & $0.258 * *$ & $0.254 * *$ \\
\hline & $(0.037)$ & $(0.041)$ & $(0.04)$ & $(0.125)$ & $(0.113)$ & $(0.116)$ \\
\hline \multirow[t]{2}{*}{ _Isize_5 } & $-0.097 * *$ & -0.079 & -0.062 & -0.003 & 0.039 & -0.005 \\
\hline & $(0.042)$ & $(0.05)$ & $(0.049)$ & $(0.14)$ & $(0.134)$ & $(0.139)$ \\
\hline \multirow[t]{2}{*}{ Leverage } & -0.038 & $0.051^{*}$ & 0.027 & -0.095 & 0.077 & 0.133 \\
\hline & $(0.025)$ & $(0.027)$ & $(0.027)$ & $(0.089)$ & $(0.078)$ & $(0.082)$ \\
\hline \multirow[t]{2}{*}{ Loandp } & $0.052^{*}$ & $0.056^{*}$ & $0.106 * * *$ & $0.278 * * *$ & $0.316^{* * *}$ & $0.330 * * *$ \\
\hline & $(0.027)$ & $(0.031)$ & $(0.034)$ & $(0.095)$ & $(0.092)$ & $(0.108)$ \\
\hline \multirow[t]{2}{*}{ Gdpgrowth } & 0.013 & 0.013 & 0.007 & -0.03 & -0.011 & -0.041 \\
\hline & $(0.015)$ & $(0.017)$ & $(0.017)$ & $(0.053)$ & $(0.055)$ & $(0.055)$ \\
\hline \multirow[t]{2}{*}{ Reporate } & 0.012 & 0.019 & 0.016 & -0.03 & -0.036 & -0.046 \\
\hline & $(0.01)$ & $(0.012)$ & $(0.012)$ & $(0.036)$ & $(0.038)$ & $(0.039)$ \\
\hline \multirow[t]{2}{*}{ Nplta } & $-0.039 * * *$ & $-0.059 * * *$ & $-0.059 * * *$ & $-0.220 * * *$ & $-0.232 * * *$ & $-0.230 * * *$ \\
\hline & $(0.01)$ & $(0.011)$ & $(0.01)$ & $(0.035)$ & $(0.033)$ & $(0.034)$ \\
\hline \multirow[t]{2}{*}{ Inflat } & $0.044 * *$ & $0.049 * *$ & $0.050 * *$ & 0.061 & -0.009 & -0.009 \\
\hline & $(0.02)$ & $(0.023)$ & $(0.023)$ & $(0.07)$ & $(0.071)$ & $(0.072)$ \\
\hline \multirow[t]{2}{*}{ _cons } & $2.380 * * *$ & $2.288 * * *$ & $2.206 * * *$ & $2.030 * * *$ & $2.659 * * *$ & $3.279 * * *$ \\
\hline & $(0.16)$ & $(0.194)$ & $(0.191)$ & $(0.581)$ & $(0.634)$ & $(0.642)$ \\
\hline $\mathrm{N}$ & 383 & 403 & 404 & 370 & 388 & 389 \\
\hline
\end{tabular}

Standard errors are in parentheses $* p<0.1, * * p<0.05, * * * p<0.001$
CAR, and yield positive returns to shareholders. For these reasons, the findings suggest that simulated BIVcap has a positive impact on the ROE. Furthermore, the findings of BIV cap for African banks is contrary to the static-trade off theory, which imply that each bank has a set optimal capital level, then an increase in capital above such level may reduce profitability.

Bank size is an important determinant of performance and achieving higher capital [25]. From the result in Table 5, Isize 2 and Isize 3 were found to positively impact ROE under Basel II model. The significant and positive coefficients shows that a unit increase in BIIcap results in a 5 percent increase in ROE for smaller banks. The results suggest that smaller banks are relatively more profitable than large banks. The result is consistent with [50] that show that smaller banks in China are easier to manage, which led to higher profitability. Still, in line with [50], smaller banks hold more capital than larger banks in emerging countries yielding higher returns on equity. This implies that smaller banks increased their capital ratio above the minimum requirements under Basel II to avoid the cost associated with low capital and the difficulties in accessing capital markets in case of emergencies, which ultimately improved the profitability of the smaller banks.

Size is not significant under Basel III and Basel IV due to major two reasons. Firstly, this can be interpreted that tighter regulations may not be favorable for smaller banks [11], resulting in insignificance size effect under Basel III and Basel IV CAR. Since large (Isize 4 and Isize 5) banks had no significant impact on performance under Basel II, it would be expected for the large size banks not to significantly impact performance for higher Basel level. According to [57], large banks tend to hold low capital buffers and as consequently higher CAR results in drop in the large banks' capital ratios, which may affect the returns on equity. Secondly, Basel III and IV require an increase in equity 
Table 7 Results for ROE: PMG, MG and DFE. Source: Authors' calculation based on data from Bloomberg database (2020)

\begin{tabular}{|c|c|c|c|c|c|c|c|c|c|}
\hline \multicolumn{4}{|l|}{$\mathrm{PMG}$} & \multicolumn{3}{|l|}{$\mathrm{MG}$} & \multicolumn{3}{|l|}{ DFE } \\
\hline & Basel 2 & Basel 3 & Basel 4 & Basel 2 & Basel 3 & Basel 4 & Basel 2 & Basel 3 & Basel 4 \\
\hline & D.ROE & D.ROE & D.ROE & D.ROE & D.ROE & D.ROE & D.ROE & D.ROE & D.ROE \\
\hline \multicolumn{10}{|l|}{$\overline{\mathrm{LR}}$} \\
\hline BIIcap & $\begin{array}{l}1.791 * * * \\
(0.49)\end{array}$ & & & $\begin{array}{l}-0.082^{* *} \\
(0.039)\end{array}$ & & & $\begin{array}{l}-0.006 \\
(0.009)\end{array}$ & & \\
\hline Gdpgrowth & $\begin{array}{l}0.149 * * * \\
(0.034)\end{array}$ & $\begin{array}{l}0.277 * * * \\
(0.048)\end{array}$ & $\begin{array}{l}0.419 * * * \\
(0.08)\end{array}$ & $\begin{array}{l}0.011 \\
(0.027)\end{array}$ & $\begin{array}{l}-0.21 \\
(0.212)\end{array}$ & $\begin{array}{l}-0.731 \\
(0.631)\end{array}$ & $\begin{array}{l}0.011 * * * \\
(0.003)\end{array}$ & $\begin{array}{l}-0.003 \\
(0.02)\end{array}$ & $\begin{array}{l}0.000 \\
(0.016)\end{array}$ \\
\hline BIIIcap & & $\begin{array}{l}1.678 * * * \\
(0.34)\end{array}$ & & & $\begin{array}{l}0.294 \\
(0.327)\end{array}$ & & & $\begin{array}{l}0.065 \\
(0.051)\end{array}$ & \\
\hline BIVcap & & & $\begin{array}{l}1.586 * * * \\
(0.338)\end{array}$ & & & $\begin{array}{l}0.035 \\
(0.096)\end{array}$ & & & $\begin{array}{l}0.022 \\
(0.027)\end{array}$ \\
\hline \multicolumn{10}{|l|}{ SR } \\
\hline ECT & $\begin{array}{l}-0.685^{* * *} \\
(0.048)\end{array}$ & $\begin{array}{l}-0.648 * * * \\
(0.054)\end{array}$ & $\begin{array}{l}-0.659 * * * \\
(0.054)\end{array}$ & $\begin{array}{l}-0.685^{* * *} \\
(0.048)\end{array}$ & $\begin{array}{l}-0.648^{* * * *} \\
(0.054)\end{array}$ & $\begin{array}{l}-0.659 * * * \\
(0.054)\end{array}$ & $\begin{array}{l}-0.966^{* * *} \\
(0.009)\end{array}$ & $\begin{array}{l}-0.799 * * * \\
(0.045)\end{array}$ & $\begin{array}{l}-0.780 * * * \\
(0.04)\end{array}$ \\
\hline BIIcap & $\begin{array}{l}-1.257 * * * \\
(0.087)\end{array}$ & & & $\begin{array}{l}-0.031^{* *} \\
(0.013)\end{array}$ & & & $\begin{array}{l}-0.006 \\
(0.009)\end{array}$ & & \\
\hline Gdpgrowth & $\begin{array}{l}-0.090^{* * * *} \\
(0.009)\end{array}$ & $\begin{array}{l}-0.241 * * * \\
(0.071)\end{array}$ & $\begin{array}{l}-0.319 * * * \\
(0.063)\end{array}$ & $\begin{array}{l}0.012 * \\
(0.007)\end{array}$ & $\begin{array}{l}-0.062 \\
(0.071)\end{array}$ & $\begin{array}{l}-0.043 \\
(0.06)\end{array}$ & $\begin{array}{l}0.011 * * * \\
(0.003)\end{array}$ & $\begin{array}{l}-0.003 \\
(0.016)\end{array}$ & $\begin{array}{l}0.000 \\
(0.012)\end{array}$ \\
\hline BIIIcap & & $\begin{array}{l}-0.981 * * * \\
(0.151)\end{array}$ & & & $\begin{array}{l}0.106 \\
(0.112)\end{array}$ & & & $\begin{array}{l}0.052 \\
(0.04)\end{array}$ & \\
\hline BIVcap & & & $\begin{array}{l}-1.019 * * * \\
(0.097)\end{array}$ & & & $\begin{array}{l}0.027 \\
(0.04)\end{array}$ & & & $\begin{array}{l}0.017 \\
(0.021)\end{array}$ \\
\hline _cons & $\begin{array}{l}3.667 * * * \\
(0.252)\end{array}$ & $\begin{array}{l}3.263 * * * \\
(0.334)\end{array}$ & $\begin{array}{l}3.514 * * * \\
(0.288)\end{array}$ & $\begin{array}{l}3.667 * * * \\
(0.252)\end{array}$ & $\begin{array}{l}3.263 * * * \\
(0.334)\end{array}$ & $\begin{array}{l}3.514 * * * \\
(0.288)\end{array}$ & $\begin{array}{l}5.099 * * * \\
(0.054)\end{array}$ & $\begin{array}{l}4.059 * * * \\
(0.26)\end{array}$ & $\begin{array}{l}4.055^{* * * *} \\
(0.214)\end{array}$ \\
\hline Hausman & 0.9997 & 0.9973 & 0.9963 & 0.9992 & 0.9996 & 0.9991 & & & \\
\hline $\mathrm{N}$ & 519 & 542 & 649 & 519 & 542 & 649 & 519 & 542 & 649 \\
\hline
\end{tabular}

Standard errors are in parentheses $* p<0.1, * * p<0.05, * * * p<0.001$

capital, and as a result, many banks in Africa may struggle to access capital from the capital market. This implies that banks would reduce their excess capital and try to maintain minimum regulatory capital [25]. As a result, size would not impact return on equity for Basel III and Basel IV. As suggested by [36] that many banks may not have ROE to attract new investors to achieve higher Basel levels.

Leverage has a negative and significant impact on performance under Basel II 1 percent level of significance. In contrast, leverage was positive and significant for Basel III and Basel IV models at 5 percent level of significance. The positive results suggest that the bank risk level became low with higher capital, such that banks became conservative by trading profitable opportunities for higher capital. Loan to deposit ratio proxy for liquidity. Loandp has no significant impact on ROE. $\mathrm{Npl}$ proxy by non-performing loan to total asset is negative and significant across the three Basel capital ratios. The banks will have to focus on credit risk management [56] and embrace
Basel prudential principles. Reporate and inflation rate have a positive impact on ROE in Basel II. Gdpgrowth, Reporate, and inflation rate are not significant under Basel III and IV.

\section{Long-run and Short-run analysis of Basel IV CAR and bank performance}

Equation 4 is estimated using three P-ARDL estimation techniques because random effects estimation results presented in Tables $7 \& 8$ could not separate the long and short-run impact of implementing Basel CAR. Therefore, the long-run impact of Basel II CAR (BIIcap), Basel III CAR (BIIIcap) and Basel IV CAR (BIVcap) and ROE were analyzed using PMG, MG, and DFE. The results for PMG indicated that BIIcap, BIIIcap, and BIVcap are significant and contribute positively to the performance of banks in the long run. Gdpgrowth also has a positive and 
Table 8 Results for ROA: PMG, MG and DFE. Source: Authors' calculation based on data from Bloomberg database (2020)

\begin{tabular}{|c|c|c|c|c|c|c|c|c|c|}
\hline \multicolumn{4}{|l|}{ PMG } & \multicolumn{3}{|l|}{$\mathrm{MG}$} & \multicolumn{3}{|l|}{ DFE } \\
\hline & Basel 2 & Basel 3 & Basel 4 & Basel 2 & Basel 3 & Basel 4 & Basel 2 & Basel 3 & Basel 4 \\
\hline & D.ROA & D.ROA & D.ROA & D.ROA & D.ROA & D.ROA & D.ROA & D.ROA & D.ROA \\
\hline \multicolumn{10}{|l|}{ LR } \\
\hline \multirow[t]{2}{*}{ BIIcap } & 0.861 & & & 0.144 & & & $0.066 * * *$ & & \\
\hline & $(2.708)$ & & & $(0.156)$ & & & $(0.023)$ & & \\
\hline \multirow[t]{2}{*}{ Gdpgrowth } & 0.099 & $0.143 * * *$ & $0.175 * * *$ & -0.018 & -0.127 & -0.006 & $0.016^{*}$ & 0.014 & 0.000 \\
\hline & $(0.442)$ & $(0.033)$ & $(0.032)$ & $(0.067)$ & $(0.164)$ & $(0.071)$ & $(0.009)$ & $(0.011)$ & $(0.013)$ \\
\hline \multirow[t]{2}{*}{ BIIIcap } & & $0.827 * * *$ & & & 0.422 & & & $0.130 * * *$ & \\
\hline & & $(0.23)$ & & & $(0.258)$ & & & $(0.029)$ & \\
\hline \multirow[t]{2}{*}{ BIVcap } & & & $0.796 * * *$ & & & 0.004 & & & $0.073 * * *$ \\
\hline & & & $(0.186)$ & & & $(0.086)$ & & & $(0.022)$ \\
\hline \multicolumn{10}{|l|}{ SR } \\
\hline \multirow[t]{2}{*}{ ECT } & $-0.715 * * *$ & $-0.686 * * *$ & $-0.688 * * *$ & $-0.715 * * *$ & $-0.686^{* * *}$ & $-0.688 * * *$ & $-0.969 * * *$ & $-0.840 * * *$ & $-0.707 * * *$ \\
\hline & $(0.06)$ & $(0.054)$ & $(0.05)$ & $(0.06)$ & $(0.054)$ & $(0.05)$ & $(0.042)$ & $(0.038)$ & $(0.033)$ \\
\hline \multirow[t]{2}{*}{ BIIcap } & -0.356 & & & 0.259 & & & $0.064 * * *$ & & \\
\hline & $(0.248)$ & & & $(0.262)$ & & & $(0.023)$ & & \\
\hline \multirow[t]{2}{*}{ Gdpgrowth } & $-0.068 * *$ & $-0.090 * * *$ & $-0.107 * * *$ & 0.003 & 0.008 & 0.013 & $0.016^{*}$ & 0.012 & 0.000 \\
\hline & $(0.032)$ & $(0.018)$ & $(0.018)$ & $(0.03)$ & $(0.015)$ & $(0.015)$ & $(0.008)$ & (0.009) & $(0.009)$ \\
\hline \multirow[t]{2}{*}{ BIIIcap } & & $-0.460 * * *$ & & & $0.108 * *$ & & & $0.110^{* * *}$ & \\
\hline & & $(0.062)$ & & & $(0.044)$ & & & $(0.024)$ & \\
\hline \multirow[t]{2}{*}{ BIV cap } & & & $-0.533 * * *$ & & & 0.015 & & & $0.052 * * *$ \\
\hline & & & $(0.064)$ & & & $(0.041)$ & & & $(0.016)$ \\
\hline \multirow[t]{2}{*}{ _cons } & $1.122 *$ & $1.396 * * *$ & $1.717 * * *$ & $1.122 *$ & $1.396 * * *$ & $1.717 * * *$ & $2.241 * * *$ & $1.784 * * *$ & $1.641 * * *$ \\
\hline & $(0.588)$ & $(0.184)$ & $(0.21)$ & $(0.588)$ & $(0.184)$ & $(0.21)$ & $(0.115)$ & $(0.111)$ & $(0.086)$ \\
\hline $\mathrm{N}$ & 519 & 542 & 649 & 519 & 542 & 649 & 519 & 542 & 649 \\
\hline
\end{tabular}

Standard errors are in parentheses $* p<0.1, * * p<0.05, * * * p<0.001$

significant impact on the performance of banks in the long run. The PMG estimation for the short run shows that BIIcap, BIIIcap, and BIVcap have a negative and significant impact on performance.

For the MG results in Table 7, BIIcap has a negative and significant impact on performance both in the short-run and the long run at a 5 percent level of significance. However, BIIIcap and BIVcap have no significant impacts on performance in the short and long run. Gdpgrowth has a positive and significant impact on performance under Basel II in the short-run, in the long-run, Gdpgrowth has no significant impact. Gdpgrowth has no significant impact both in the short and long run for Basel III and Basel IV. For the MG estimation results, as shown in Table 7, because the long-run coefficient is positive and insignificant for Basel III and IV, Basel II is negatively significant. It implies that the long-run impact of Basel capital ratios and return on equity seems to be unstable. Nevertheless, the study uses the Hausman test to select the more appropriate estimation technique for the long-run relationship for Eq. 5. According to the Hausman test results regarding the long-run relationship between $\mathrm{MG}$ and PMG, PMG is a better estimation technique.
Considering the DFE result in Table 7, the three levels of Basel capital ratios have no significant impacts on the performance of banks in the long- and short-run. However, the DFE result in the short run reveals that the Gdpgrowth has a positive and significant impact under Basel II and the same impact in the long run at the 1 percent level of significance. According to [58], the DFE estimation method is the opposite extreme of the MG estimation method, which restricts both the long and the short-run coefficients. As shown in the DFE estimation results in Table 7, the Basel capital ratio and return on equity have a long-run correlation, and the longrun coefficient is insignificantly negative. Hence, the longrun effect is not stable, possibly owing to the DFE estimation restrictions, and the short-run coefficient is significantly negative. According to the Hausman test results regarding the long-run relationship between MG and DFE, DFE is a better estimation technique.

However, considering the better estimator between PMG, MG, and DFE, from the results presented in Table 7, as far as the sign, significant impact, and the theoretical consistency of the estimated coefficients in the results presented, the PMG performs the best among all the three estimation 


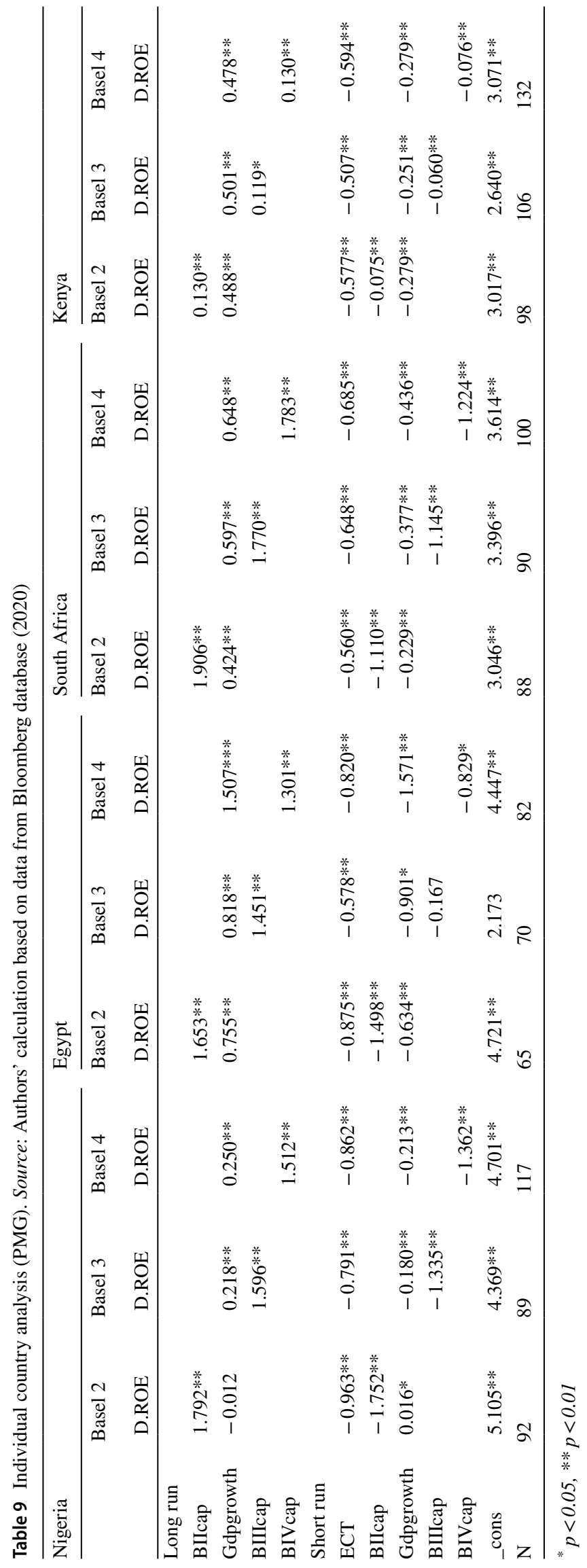


techniques. This study result confirms other literature [52, $53,58]$ that PMG is a better estimator. BIVcap persistents positive and significant impact on the performance of banks in the long run under PMG. This is inconsistent with the static trade-off theory, which suggests that the effect would be negative. BIVcap negative and significant impact in the short-run is consistent with the static trade-off theory where it is expected that compliance to BIVcap will have a negative impact on the performance of banks in Africa. Hence, our findings are explained by trade-off theory the only in the short-run. The results are also contrary to the M\&M theory as BIVcap negatively impact performance in the short-run. The negative impact of Basel IV CAR on bank performance could arise from cost of issuing new equities and increasing the cost of lending, which may reduce the volume of loans. The error correction term (ECT) in Tables 7 is significant and negative, confirming that there is co-integration among the panel variables, indicating the existence of a stable and converging long-run relationship between Basel capital ratios, Gdpgrowth, and return on equity.

Table 9 reports country by country potential impacts of Basel IV CAR on the performance of banks in Africa using PMG as a better estimator over MG and DFE on the grounds of better precision, according to [53], significance and theoretical consistency [52]. The short and long-run estimations were estimated for individual countries with sufficient bank data (Nigeria, Egypt, Kenya, and South Africa). Its relevance is to examine the extent to which the impact of higher CAR varies by re-estimating the models in Table 7 . Table 9 reports the results for individual African countries in the sample. The error correction term (ECT) in Table 9 shows that there is co-integration among the panel variables in each country. To summarize, there is empirical evidence that the Basel IV capital ratio will have a significant positive impact on the performance of banks in Africa as a whole and in the individual African countries in the long-run. Also, the implementation of the Basel IV capital ratio will have a significant negative short-run impact on the performance of the entire African banking sector and the individual countries.

\section{Discussion of findings}

The study examines the potential impact of Basel IV CAR on the performance of commercial banks in selected African countries using static and dynamic panel models. Basel II capital ratios require 8 percent minimum of Tier1 capital divided by RWA. Basel III and Basel IV capital ratios require 10.5 percent minimum of tangible common equity divided by RWA. Capital is a major determinant of bank performance. With increase in equity capital for Basel III and IV CAR [14], the new Basel CAR in the literature were expected to reduce profits, leading to a negative impact on performance $[59,60]$. The results are also contrary to the expected hypothesis that Basel IV will negatively impact banks' performance in Africa. The results from African countries have shown otherwise for ROE, ROA, and NIM, that Basel IV CAR would positively improve African banks' performance. Furthermore, it was determined that smaller banks (bank size) had improved performance under Basel II for ROE.

Size (smaller banks) have a more positive and significant impact on NIM under Basel II, III and IV. This suggests that smaller banks are easier to manage to meet higher CAR and generate more interest income and better efficient if well-capitalized [8, 61]. Under Basel II, Basel III, and Basel IV, size has no significant impact on returns on equity or assets for large banks. When introducing higher Basel levels, the policy implication is that the African government would ensure that the Basel IV CAR regulations are adapted for smaller banks. The smaller banks had higher returns on equity, returns on assets, and persistent net interest income relative to the large banks with higher Basel levels. One way is to ensure that compliance to higher Basel CAR would not impose high costs that may force such banks to increase the cost of lending, which may negatively affect the smaller banks' interest income.

Leverage was expected to have a negative impact on bank performance because the non-risk weighted leverage ratio introduced by BCBS in Basel III and IV should act as a backstop against risk. Herein, either a bank increase capital to take on more risk or reduce lending [14, 62]. The positive results for leverage on ROE under Basel III and Basel IV suggest that the African bank risk level became low with higher capital. Or the banks became conservative by trading profitable opportunities for higher capital. Loan to deposit ratio appears to exert a positive influence on ROA and NIM. This suggests that higher CAR may be an indication of bank ability to utilize its deposits to issue more loans and leads to higher returns on assets and interest income for African banks. Non-performing loan to total asset (Nplta) has a negative and significant impact for ROE, ROA and NIM. The banks will have to focus on credit risk management [56] and embrace Basel prudential principles. Finally, for macroeconomic variables, inflation exerts a significant impact on bank asset earnings (ROA).

For the short-run and long-run impact of Basel capital ratios on performance, it is expected that higher Basel levels would negatively affect the return on equity in the short-run. Nevertheless, investors could willingly invest in the banks in anticipation of increasing returns in the future as bankruptcy risk declines with higher equity capital. The negative shortrun impact of Basel capital ratios in Africa also in line with [63] for Basel III in EU; [38] for Egypt. Basel III higher capital requirement introduced in Europe decreased return on equity in many European banks [63]. High cost of capital 
is identified as a factor contributing to Basel III's negative impact on performance in [38] and [63]. The Basel IV capital ratio will not be spared from having a negative impact on banks' performance in Africa in the short run. Furthermore, macroeconomic variable contributes to the positive performance of banks in the long-run but does not contribute to performance in the short-run. The result is consistent with [50]. The positive impact of Gdpgrowth on performance, in the long run, suggests because the banks are adequately capitalized, that during economic boom, the commercial banks will have the ability to increase lending rather than being constrained, resulting in improved performance.

\section{Conclusions and recommendations}

The purpose of higher CAR is to reduce the probability of banking crises, which is prevalent in Africa. Nonetheless, it has certain implications for bank performance especially in Africa where lending is currently low and costly, with high net interest but poor performance. Basel IV is proposed to be implemented in 2023, while most African banks lag behind in implementing existing Basel CAR. Hence, this study contributes to understanding higher CAR implications for banks in Africa. The findings provide insight for African banks and regulatory authorities as to the implementation of the proposed new Basel IV framework or not.

This study concludes that the performance of banks, especially the smaller banks improved with higher Basel CAR. The analysis results confirm that the African banking sector needs a tighter CAR for a more efficient and profitable banking sector to finance more lending to corporates and households. Overall, the potential impact of Basel IV CAR for performance is satisfactory. The benefit of higher Basel CAR will increase African banks' capital adequacy to enable these banks to take on more risks to support growing African economies. Practically, for banks to take on more risk to support African growing economies, regulatory authorities and policymakers need to agree to implement higher Basel CAR to eliminate moral hazard problems where banks operate with low capital buffers, causing distress and failures that negatively affect the economy. In other words, it would be beneficial for regulatory authorities in Africa to implement Basel IV CAR to increase these banks' resilience and reduce the spate of bank failure due to capital inadequacies.

It is suggested that if Basel IV be implemented, regulatory authorities should allow banks to adopt the higher Basel levels over a medium-term period to allow banks to prepare and prevent any macroeconomic costs that can have negative effect on bank performance in the short term. This may reduce the negative impact of the regulatory requirements, especially on smaller banks. Consequently, it is recommended that regulatory authorities in Africa should embrace the Basel CAR with caution. This study suggests that higher CAR of Basel IV will have a positive and significant impact on the performance of banks in Africa in the long run. Also, implementing higher Basel regulations empowers regulators' supervisory functions to monitor banks.

\section{Declarations}

Conflict of interest On behalf of all authors, the corresponding author states that there is no conflict of interest.

\section{References}

1. Bandt, D., B. Camara, A. Maitre, and P. Pessarossi. 2018. Optimal capital, regulatory requirements and bank performance intimes of crisis: Evidence from France. Journal of Financial Stability 39: 175-186.

2. Talbot, D., E. Ordonez-Ponce. 2020. Canadian banks' responses to COVID-19: A strategic positioning analysis. Journal of Sustainable Finance \& Investment. 1-8. https://doi.org/10.1080/20430 795.2020.1771982

3. Papadamou, S., D. Sogiakas, V. Sogiakas, K. Syriopoulo. 2021. The role of net stable funding ratio on the bank lending channel: Evidence from European Union. Journal of Banking Regulation. https://doi.org/10.1057/s41261-021-00144-6

4. Chiaramonte, L., and B. Casu. 2017. Capital and liquidity ratios and financial distress. Evidence from the European banking industry. The British Accounting Review 49 (2): 138-161.

5. Roulet, C. 2018. Basel III: Effects of capital and liquidity regulations on European bank lending. Journal of Economics and Business. 95: 26-46.

6. Papadamou, S., D. Sogiakas, V. Sogiakas, K. Toudas. 2021. The prudential role of Basel III liquidity provisions towards financial stability. Journal of Forecasting 40(7): 1133-1153.

7. Berger, Bouwman. 2013. How does capital affect bank performance during financial crises? Journal of Financial Economics 109 (1): $146-176$

8. Francis, M. 2013. Determinants of commercial bank profitability in Sub-Saharan Africa. International Journal of Economics and Finance 5 (9): 134-147.

9. Chironga, M., L. Cunha, H.D. Grandis, and M. Kuyoro. 2018. African retail banking's next growth frontier. London: Mckinsey \& Company.

10. Lotto, J. 2016. Efficiency of capital adequacy requirements in reducing Risk-Taking behavior of Tanzanian commercial banks. Research Journal of Finance Accounting 7 (22): 110-118.

11. Nkopane, T. 2017. The relevance of the Basel III Accord within the South African banking system. South Africa: Wits University.

12. Hoenig, T. 2012. Get Basel III right and avoid Basel IV. Washington: Federal Deposit Insurance Corporation.

13. BCBS. 2009. Strengthening the resilience of the banking sector. Basel: Basel Committee on Banking Supervision.

14. BCBS. 2017. Basel III: Finalising post-crisis reforms, 1-162. Basel: Basel Committe on Banking Supervision.

15. BCBS. 2016. Standardised Measurement Approach for operational risk, 1-18. Basel: Basel Committee on Banking Supervision.

16. Swamy, V. 2018. Basel III capital regulations and bank profitability. Review of Financial Economics 36 (4): 307-320. 
17. Giordana, G.A., and I. Schumacher. 2017. An empirical study on the impact of Basel III standards on Banks' default risk: The case of Luxembourg. Journal of Risk and Financial Management 10 (2): 8.

18. Oyetade, D., A. Obalade, and P.-F. Muzindutsi. 2020. Impact of the Basel IV framework on securitization and performance of commercial banks in South Africa. Banks and Bank Systems 15 (3): 95-105.

19. Myers, S.C. 1984. The capital structure puzzle. The Journal of Finance. 39 (3): 574-592.

20. Admati, A.R., P.M. DeMarzo, M.F. Hellwig, and P.C. Pfleiderer. 2013. Fallacies, irrelevant facts, and myths in the discussion of capital regulation: Why bank equity is not socially expensive. Max Planck Institute for Research on Collective Goods 23: $1-77$.

21. Osborne, M., A. Fuertes, A. Milne. 2012. Capital and profitability in banking: Evidence from US banks. In: 3rd Emerging Scholars in Banking and Finance Conference, Cass Business School. 1-54.

22. Diamond, Rajan. 2000. A theory of bank capital. The Journal of Finance. 55 (6): 2431-2465.

23. Fender, I., U. Lewrick. 2016. Adding it all up: The macroeconomic impact of Basel III and outstanding reform issues. Bank for International Settlement BIS Working Paper No 591.

24. Cummings, J.R., and S. Wright. 2016. Effect of higher capital requirements on the funding costs of australian banks. Australian Economic Review 49 (1): 44-53.

25. Malovaná, S. 2017. Banks' capital surplus and the impact of additional capital requirements institute of economics studies (IES) charles university working paper 1-34.

26. Gabriel, G. 2016. The impact of the basel 3 capital requirements on the performance of European banks. Liège: University of Liège.

27. Le, T.N.L., M.A. Nasir, T.L.D. Huynh. 2020. Capital requirements and banks performance under Basel-III: A comparative analysis of Australian and British banks. The Quarterly Review of Economics and Finance. https://doi.org/10.1016/j.qref.2020.06.001.

28. Hofmann, P.S. 2011. Determinants of the proitability of the US banking Industry. International Journal ofBusiness and Social Science 2: 255-269.

29. Sanders, T.B. 2015. The unintended consequences of Basel III: Reducing performance ratios and limiting bank acess to equity funding markets. Quarterly Journal of Finance and Accounting 53 (1/2): 97-144.

30. Dietrich, A., and G. Wanzenried. 2011. Determinants of bank profitability before and during the crisis: Evidence from Switzerland. Journal of International Financial Markets, Institutions and Money 21 (3): 307-327.

31. Cohen, B.H., and M. Scatigna. 2016. Banks and capital requirements: Channels of adjustment. Journal of Banking \& Finance 69: S56-S69.

32. Awdeh, A., C. El-Moussawi, and F. Machrouh. 2011. The effect of capital requirements on banking risk. International Research Journal of Finance Economics 66: 133-146.

33. Manlagnit, M.C.V. 2015. Basel regulations and banks' efficiency: The case of the Philippines. Journal of Asian Economics 39: 72-85.

34. Banerjee, R., S. Majumdar (Eds.). 2017. Does financial regulation influence bank efficiency? A study on UAE banking sector. Cham: Springer.

35. Ayadi, R., S.B. Naceur, B. Casu, and B. Quinn. 2016. Does Basel compliance matter for bank performance? Journal of Financial Stability 23: 15-32.

36. Pinheiro, F.A.P., J.R.F. Savóia, and J.R. Securato. 2015. Basel III: Impact on Banks in Brazil. Revista Contabilidade \& Financas 26 (69): 345-361.
37. Abdrahamane, K., L. Xi, B.B. Alpha, and M. Kargbo. 2017. An empirical study on government regulation, bank risk and bank performance: Case of Mali. Journal of Management Policies and Practices 5 (1): 1-8.

38. Naceur, Kandil. 2009. The impact of capital requirements on banks' cost of intermediation and performance: The case of Egypt. Journal of Economics and Business 61 (1): 70-89.

39. Obamuyi, T.M. 2013. Determinants of banks' profitability in a developing economy: Evidence from Nigeria. Organizations Markets in Emerging Economies 4 (8): 97-111.

40. Sadien, E. 2017. The impact of the change from Basel II to Basel III on the profitability of the South African Banking Sector. Capetown: University of Capetown.

41. Ramlall, I., and F. Mamode. 2017. A Critical Assessment of Basel III and its Implications on the Mauritian Banking Sector. Journal of African Business 18 (1): 70-101.

42. Naceur, Omran. 2011. The effects of bank regulations, competition, and financial reforms on banks' performance. Emerging Markets Review 12 (1): 1-20.

43. Okoye, L.U., K.A. Adetiloye, O. Erin, and G.O. Evbuomwan. 2017. Impact of banking consolidation on the performance of the banking sector in Nigeria. Journal of Internet Banking and Commerce 22 (1): 1-15.

44. Ozili. 2019. Basel III in Africa: Making it Work. African Journal of Economic and Management Studies 10(4): 401-407. https://doi.org/10.1108/AJEMS-05-2019-0206.

45. Dedu, V., and D.C. Niţescu. 2012. Basel III-between global thinking and local acting. Theoretical and Applied Economics 19 (6): 5-12.

46. Gyntelberg, J. 2018. The consequences of "Basel IV"-a quantitative impact study. 1-14. Available from: https://www.voeb. de/download/die-folgen-von-basel-iv-englisch.

47. Brei, M., L. Gambacorta. 2014. The leverage ratio over the cycle. Bank for International Settlement BIS Working Paper No 471. 1-39.

48. Cardone-Riportella, C., R. Samaniego-Medina, and A. TrujilloPonce. 2010. What drives bank securitisation? The Spanish experience. Journal of Banking \& Finance 34 (11): 2639-2651.

49. Mapororo, B. 2018. The determinants of capital structure and internal factors that influence the performance of commercial banks in Botswana. Cape Town: University of Cape Town.

50. Tan, Floros. 2013. Risk, capital and efficiency in Chinese banking. Journal of International Financial Markets, Institutions and Money 26: 378-393.

51. Bakoush, M., R. Abouarab, and S. Wolfe. 2019. Disentangling the impact of securitization on bank profitability. Journal of Research in International Business Finance 47: 519-537.

52. Goswami, G.G., and S.H. Junayed. 2006. Pooled mean group estimation of the bilateral trade balance equation: USA vis-à-vis her Trading Partners. International Review of Applied Economics 20 (4): 515-526.

53. Pesaran, M.H., Y. Shin, and R.P. Smith. 1999. Pooled mean group estimation of dynamic heterogeneous panels. Journal of the American Statistical Association 94 (446): 621-634.

54. Blackburne, E.F., and M.W. Frank. 2007. Estimation of nonstationary heterogeneous panels. The Stata Journal 7 (2): 197-208.

55. Ozili, P.K. 2015. Determinants of bank profitability and basel capital regulation: Empirical evidence from Nigeria. Research Journal of Finance and Accounting 6 (2): 124-131.

56. Athanasoglou, P., M. Delis, and C. Staikouras. 2006. Determinants of bank profitability in the South Eastern European region, 1-32. Germany: Munich University Library.

57. Mamatzakis, Bagntasarian. 2019. The nexus between underlying dynamics of bank capital buffer and performance. School of Business, Management and Economics, University of Sussex Business School. 1-57 
58. Tan, A. 2009. pooled mean group analysis on aid and growth. Applied Economics Letters 16 (16): 1597-1601.

59. Lee, T.-H., and S.-H. Chih. 2013. Does financial regulation affect the profit efficiency and risk of banks? Evidence from China's commercial banks. The North American Journal of Economics and Finance 26: 705-724.

60. Cosimano, T.F., D. Hakura. 2011. Bank behavior in response to Basel III: A cross-country analysis. Working paper WP/11/119. International Monetary Fund 1-35.

61. Tan, Y. 2016. The impacts of risk and competition on bank profitability in China. Journal of International Financial Markets, Institutions and Money 40: 85-110.

62. Munoz ,S., P. Soler. 2017. Basel III End Game. Regulations and Public Policies [Internet]. 20/04/2018:[1-8 pp.]. Available from: https://www.bbvaresearch.com.

63. Knyazeva, A. 2016. Basel regulations and its future impact on return on equity risk and banking. Luxembourg: Luxembourg School of Finance.
Publisher's Note Springer Nature remains neutral with regard to jurisdictional claims in published maps and institutional affiliations.

Damilola Oyetade (Ph.D.) is a Postdoctoral Research Fellow (Finance) in the School of Accounting, Economics and Finance at the University of KwaZulu-Natal, South Africa.

Adefemi A. Obalade (Ph.D.) is a Postdoctoral Research Fellow (Finance) in the School of Accounting, Economics and Finance at the University of KwaZulu-Natal, South Africa.

Paul-Francois Muzindutsi (Ph.D.) is a Professor of Finance in the School of Accounting, Economics and Finance at the University of KwaZulu-Natal. 